\title{
OBST ACLES IN THE STRUCTURE OF INTERESTS AND POWERS TO THE INTRODUCTION OF EFFICIENT MONEY INCENTIVES *
}

\author{
Louis HÉTHY and Csaba MAKÓ \\ Hungarian Academy of Sciences, Budapest, Hungary
}

Received December 1970

The paper gives an analysis of discrepancy between organizational goals and labor's behavior at a Hungarian engineering enterprise. The occasional partial or complete rejection by workers of enterprise goals like the increase of production, the introduction of a new incentive plan, the authors assume, can be traced back to the lack of multilateral and lasting compromise of interests, to the balance of powers within the organization, and to a set of interacting microand macrofactors of the socioeconomic environment.

\section{The problem to be discussed}

There is a prevailing belief in Hungarian society that, by means of the decentralized scheme of the centrally planned economy introduced two years ago, most obstacles to the growth of industrial efficiency can be overcome, directly or indirectly, by differential monetary incentives. For the past two years, a part of the enterprises, profits has been used for differential incentive bonuses up to 80 percent of salary for top management, 50 percent for middle managers, and 15 percent for wage earners. The considerable share in profits has seemed to be a driving force for management, and managers have made manifold attempts to increase the efficiency and profits of the enterprises. They have, however, usually failed in their efforts to get workers to contribute more to enterprise objectives; the obstacles to the growth of efficiency have often continued to exist on the shop floor.

* The summing up of a substantial study about labor-management and intralabor conflicts in a business organization of a centrally planned economy (Budapest, 1970). 
As a general rule at several enterprises labor has rejected enterprise goals and there has remained a constant gap between requirements set up by management and the everyday activities of employees. The lack of sympathy with management's objectives has been manifested in many ways: workers have resisted attempts to maintain strict discipline, they have deliberately restricted output and performed work of poor quality, etc. Many managers and economic leaders are convinced that this discrepancy between enterprise goals and labor's behavior can be attributed to inadequacies in monetary incentives and to the lack of fair wage differentials among workers.

Our proposition is that causal relations are not so unambiguous and simple - inadequacies in wage incentives, though closely connected with difficulties in workshops, cannot be a root cause for discipline defects and restriction of output since they themselves are also a surface problem. The root cause for difficulties, including also the lack of fair wage differentials, lies in the structure of interests and powers within the organization, based on certain micro- and macrofactors of the social and economic environment. These factors originate from the present regulations set up by social and economic central agencies, and from the characteristics of the overall socioeconomic system of industry that has come into existence as a result of the development of the past few decades.

To place our proposition in a sharper focus, production difficulties in workshops cannot be solved solely by the revision of the incentive system. The solution of present problems, including the introduction of efficient wage differentials, requires complex changes in the structure of interests and powers within the enterprise, that is, complex modifications in the social and economic background.

\section{The enterprise, its workers, and its problems on the shop floor}

Our proposition has been supported by the results of a sociological survey carried out in an engineering factory in Western Hungary. The firm to be discussed plays an important role in the economic progress of the country. It manufactures railway cars, tank wagons, various axles for trucks and buses - mostly for export. It has also just started the production of heavy-duty diesel engines under licence from a leading 
West German firm. In its different units the enterprise employs a total of about 15,000 physical workers.

The unit at which our sociological survey took place manufactures bodies for railway cars. Its employees, about two hundred locksmiths and welders, work in groups according to the nature of their tasks. The workgroups are paid directly on the basis of how much they produce, according to a straight piece-rate system. As the groups' productivity increases, its earnings also increase, and, conversely, as its output falls, there is a corresponding drop in wages. Within the group, earnings are not divided equally, but on the basis of the personal wage rates of the members. The wage plan thus has the purpose of functioning as a group incentive and as an individual incentive at the same time. The activities of groups are directed by nine foremen and two senior foremen.

The management of the enterprise was not satisfied with discipline and work intensity at the unit, for individual workers and even groups often restricted output and showed large-scale mobility which endangered the continuity of production in workshops. This was why the managers revised the wage plan (1968). The revision was based on the widespread belief that setting proper wage differentials would solve the problem.

The wage plan, as a group incentive, seemed to be all right. But as an individual incentive it seemed to be unresponsive to the management's efforts geared directly to the quantity of output. The personal wage rates, regulating the relative ratio of individual earnings within the group, had been set according to a central service and merit rating system. The favorite factors of the system - the period of enterprise service and the qualification of professional skill - were irrelevant to individual output; namely, neither professional practice nor qualification was needed for the highly routine nature of the work. Thus, personal wage rates had two major insufficiencies: (1) they did not properly reflect individual efforts, and they ensured different earnings to workers of equal performance; (2) the scale of individual wage differentials, originating from the rates, did not reflect the possible differences in individual output because it was too narrow. To correct these inadequacies, the management abolished the central service and merit rating system and authorized the foremen and the workgroups, since they had the most adequate and accurate information about the efforts of individuals, to set new personal wage rates.

The new personal wage rates set by foremen and labor were, how- 
ever, even less responsive to the management's objectives than the previous ones. Individual wage inequities continued to exist and the scale of individual wage differentials became even narrower (previous index of differentials: 0.13 ; new index: 0.10 ). That is how foremen and workers made a step to defeat the purposes of the wage plan.

In the course of our survey we examined empirical and logical connections among the level (scale) of individual wage differentials approved by the employees, the structure of interests and powers within the organization, and the socioeconomic environment in the background. Our survey endeavored to cover all the important factors motivating the behavior of workers and foremen. The information needed came from three sources: (1) structured interviews with each worker in the unit with the help of a substantial questionnaire; (2) unstructured interviews with the majority of workers, and with the foremen and the representative of top management; (3) data collected by the bureaucracy of the enterprise.

\section{Labor-management structure of interests and powers}

The long-run economic success of a business organization requires workable cooperation between the two major participants in production, managers and workers, i.e., the formation of enterprise goals acceptable to both of them. Cooperation and the working out of common goals can be based only on the solution of conflict situations produced by divergences in the interests of management and labor, on the existence of compromise situation in which the two major participants have a relatively good bargain in comparison with their contributions to the success of organization. Compromise, however, does not develop automatically from conflicts; a certain balance of power and influence is necessary between management and labor to advance the process.

In the case of the enterprise examined, the cooperation between managers and workers was not satisfactory: the employees rejected the goals that the employers had prescribed for them. Conflict situations seemed to be lasting and the equilibrium of opposing powers seemed to be upset.

On the assumption that the structure of divergent interests and various powers is profoundly determined by the social and economic environment, we have examined several factors that might have had a 
direct or indirect effect on the interests, goals, influence, and behavior of people within the framework of the organization. Since the enterprise belongs to a centrally planned economy, we have paid special attention to regulations by the central agencies.

The clashes between the interests of management and labor focused on wages and output (the two were closely connected in the piece-rate system employed).

The management, stimulated by its considerable share in profits and using the prices of the international market as guides, tried to choose a profit-maximizing mix in its production possibility set (the plant managers have had remarkable freedom in such decisions since the introduction of a decentralized scheme in 1968). It made attempts to develop new dynamic and profitable branches (the production of heavy-duty diesel engines, etc.), as traditional branches, including the manufacturing of railway cars, proved to be unprofitable and subsidies were to be cut off by the central agencies. Railway cars could not, however, be shut down right away, and that is why cuts in the production costs were necessary. In the workshops there was no possibility for introducing improvements or innovations in the obsolete technology that had been used for decades and thus the management decided to cut labor costs, to decrease wages per unit of output.

Labor, as its share in profits was low, was motivated by wages. Workers were ready to make extra efforts for extra pay and aimed their activities at maximizing earnings. The employees in the workshops, mostly of agricultural origin, were hard-working people, in whose thinking wages were fundamental in relation to their families'living standards and also in measuring their importance in relation to others in and out of the factory. The workers, consequently, opposed the managers'goal directed at "sweating" them simply to "fill the enterprise coffers."

Responsibility for the divergences of management and labor interests cannot, however, be fixed entirely on the profit-sharing system, on the high level of production costs in comparison to prices (owing to a backward technology), and on the cutting of governmental subsidies and on other economic factors mentioned. In the lasting confrontation a prominent part was played by the control of central agencies over the level of wages. The central regulations practically pegged per capita wages on a roughly equal level in all engineering enterprises owned by the state. Any noticeable increase had to be covered from the share of profits to be divided among the participants in production. The share 
was considerable in relation to the amount of the salaries of managers but infinitely small in relation to the total amount of wages of employees.

Thus the management made attempts to cut wages per unit of output and, at the same time, to keep per capita wages unchanged: they required extra efforts from the employees without being willing, or in fact being able, to give them extra reward. 1

Only on the basis of the conditions of the enterprise and of the specified rules the management was obliged to follow can we understand the contradictory features of its incentive policies. The management pressed the workgroups for increased production, and to this end it employed an efficient group incentive, the piece-rate system, without - at least theoretically - any ceiling on earnings. It promised extra reward for extra output. Moreover, as we have said, the management made attempts also to improve individual incentives by revising its service and merit rating system. But when workgroup productivity and wages rose appreciably it arbitrarily reset piece rates, cutting also wages per capita and pegging them in one year's average to the level permitted by the central agencies. Piece rates were being continually cut. In 1969 whey were cut twice, and that meant a twenty percent loss for labor in wages. ${ }^{2}$,

Labor-management conflicts on the level of wages were of utmost gravity, as wages held a top place in each worker's evaluation of his job. They often told us: "We do not come here to produce railway cars, but to earn a living." The reasons for the money-centered attitude of labor could be found partly in the present level of living standards in the

\footnotetext{
${ }^{1}$ The control of central agencies over wages supposedly was aimed at avoiding certain undesirable effects of the economic reform. The total freedom of managers motivated by their share in profits might have rapidly led to growing wages for a part of the workers and to unemployment for others, and/or to a high rate of inflation and to the disequilibrium of supply and demand in the market of consuming goods. Such a process would have been followed by sharp and open social conflicts instead of the concealed ones described in this paper.

2 The regulations of the central agencies do not necessarily call into existence such management policies. In several engineering enterprises the poor standards, the poor scheduling of jobs, and the insufficiencies in the supply of material and in the maintenance of tools automatically prevent management from building up workable incentive systems. Management in other firms, enjoying vast subsidies and favorable internal market conditions set by the central agencies, naturally refrain from pushing workers to increased efforts. In all these cases a tacit agreement is forced by management on labor: it does not offer extra pay, but it does not require extra work either.
} 
Table 1

Workers' evaluation of work.

The extent of possibilities offered by work for

\begin{tabular}{llll}
\hline $\begin{array}{l}\text { Learning } \\
\text { new things }\end{array}$ & $\begin{array}{l}\text { Using one's } \\
\text { own ideas }\end{array}$ & $\begin{array}{l}\text { Doing } \\
\text { interesting } \\
\text { tasks }\end{array}$ & $\begin{array}{l}\text { Making profit of } \\
\text { one's professional } \\
\text { knowledge }\end{array}$ \\
\hline
\end{tabular}

The actual

situation

1.40

1.70

1.58

1.95

The expected situation

Gap

Note: The indices above represent the averages of evaluations given by about two hundred workers. Mark 3 means a large possibility, while mark 1 no possibility at all.

country and partly in certain aspects of the environment that hindered the satisfaction of higher-level needs of individuals within the factory. Working people were frustrated by the monotony of the routine job, by their inability to advance in professional knowledge, by the pressures to which they were subject as they tried to do work of quality instead of quantity, and by their inability to achieve a measure of respect and autonomy in their everyday activities.

The workers had practically no change of promotion to the positions

Table 2

Workers' evaluation of promotion.

The role played by the promotion factors of

\begin{tabular}{|c|c|c|c|c|c|}
\hline $\begin{array}{l}\text { Individual } \\
\text { perform- } \\
\text { ance }\end{array}$ & $\begin{array}{l}\text { Enterprise } \\
\text { service }\end{array}$ & $\begin{array}{l}\text { Profes- } \\
\text { sional } \\
\text { knowledge }\end{array}$ & $\begin{array}{l}\text { Approval } \\
\text { by fellow } \\
\text { workers }\end{array}$ & $\begin{array}{l}\text { Friends in } \\
\text { top man- } \\
\text { agement }\end{array}$ & $\begin{array}{l}\text { Social } \\
\text { (trade union } \\
\text { and party) } \\
\text { functions }\end{array}$ \\
\hline
\end{tabular}

$\begin{array}{lrrrrrr}\begin{array}{l}\text { The actual } \\ \text { situation }\end{array} & 1.88 & 2.01 & 2.13 & 1.39 & 2.11 & 2.13 \\ \begin{array}{l}\text { The expected } \\ \text { situation }\end{array} & 2.34 & 2.28 & 2.50 & 2.32 & 1.07 & 1.31 \\ \text { Gap } & -0.46 & -0.27 & -0.37 & -0.93 & +1.04 & +0.82\end{array}$

Note: The indices above represent the averages of evaluations given by about two hundred workers. Mark 3 means a significant role, while mark 1 means an insignificant one. 
of foremen and senior foremen, that is, to the posts usually within the limits of workers'career structure. On the one hand, in the unit to be shut down the number of such positions was gradually decreasing, and on the other hand, promotion at the enterprise was based on factors that mostly were beyond the control of workers.

For the lack of satisfaction of their higher-level needs workers mostly sought compensation in money.

The series of management victories and labor defeats, good bargains on the one side and poor bargains on the other, resulted in a lasting confrontation, the existence of which reflected also a lack of equilibrium of powers, an inequity of opposing forces at the enterprise. The management was wielding an overwhelming power that the trade union, designed for the defense of the interests of labor, was incapable of or unwilling to counterbalance. Incentive policies at the enterprise, including the continual cuts in piece rates, were approved also by the executive of the trade union. The union, as a heritage of a previous period, united in its ranks all sorts of members of the business organization, from unskilled workers to top managers. Several trade-union positions were occupied by foremen, by middle managers, and even by top managers. Its executive had a considerable share in enterprise profits. In fact, top union leaders and top enterprise managers, despite occasional spectacular discussions between them, seemed to be a monolithic group to the workers. Though labor's rights of taking part in enterprise affairs, including also decisions about the wage plan and promotion, were ensured, they had no means and no proper platform to do so. The functioning of the institution of workers' direct participation in management decisions relevant to their interests proved to be profoundly formal. The dominant push from labor might have come only through the informal organization of workers, which sometimes had substantial powers, rival to those of management, but which in most cases was rather weak.

\section{Intramanagement and intralabor structure of interests and powers}

It has been suggested that the basic conflict is between management and labor and that it arises from certain micro- and macroeconomic and social factors created by the present regulations of the central agencies and by the realities of the socioeconomic progress of past decades. On 
the assumption, however, that people generally act under the influence of their environment, it seems obvious that neither enterprise managers nor factory workers are a homogeneous social unit, that both are divided into several strata representing also divergent interests and goals. Thus, the next step of our examination was to take under scrutiny the intramanagement and intralabor structure of interests and powers, which also modifies the course of overall enterprise clashes.

Within management, the foremen and other low-level supervisors formed a separate stratum with objectives often contradicting the interests of top managers. These "men in the middle" had substantial powers to influence the production and wages of workgroups. For example, the functional departments of the management were incapable of controlling production problems - including supply of material and maintenance - and their solution was up to the foremen (this situation originated from the primitive level of technology characteristic of the small factories of the past). But top managers, believing in the efficiency of centralization within the enterprise, did not take into consideration the influence of these people. Accordingly, nothing had been done to ensure their cooperation: foremen received a salary inferior to that of the best workers, and this state of affairs practically stagnated regardless of their special efforts or negligence. As a result, management policies were a matter of indifference to foremen. They neither promoted nor hindered the success of management's attempts to encourage workgroup and individual output. They restricted their activities to the performance of routine tasks. Their substantial powers mostly remained potential and their role in the discussions between top management and labor was only of third-rate importance.

Labor was also divided into separate strata. Each worker considered management's incentive policies hostile to his interests and protested management's efforts to cut labor costs. Workers devotion to money was general. However, personal wage rates. seniority in the organization, professional skills, household expenses, structure of consumption, traditions, and other factors produced a similar compartmentalization within them that occured at management level. The two factors responsible for the division of workers into strata with divergent interests and various powers were the following .

(1) One factor was the actual level and the future prospect of the individual's earnings - in fact, his actual and expected economic position in the organization. Both were dependent on wages per capita in 
Table 3

The growth of personal wage rates by years of enterprise service.

\begin{tabular}{lcc}
\hline \multirow{2}{*}{$\begin{array}{l}\text { Years of enterprise } \\
\text { (professional) }\end{array}$} & \multicolumn{2}{c}{ Growth related to the total increase of 30 years $(\%)$} \\
\cline { 2 - 3 } service & $\begin{array}{l}\text { Wage rates set by the } \\
\text { enterprise rating system }\end{array}$ & $\begin{array}{l}\text { New wage rates set } \\
\text { by foreman and labor }\end{array}$ \\
\hline $0-2$ & 40.0 & 46.4 \\
$2-4$ & 8.2 & 10.0 \\
$4-6$ & 16.2 & 7.3 \\
$6-8$ & 9.7 & 17.0 \\
$8-10$ & 2.8 & 15.4 \\
$10-12$ & 16.7 & 3.0 \\
$12-14$ & 3.8 & 0.0 \\
$14-30$ & 2.6 & 0.9 \\
& 100.0 & 100.0 \\
\hline
\end{tabular}

Note: $12-14$ years of enterprise of professional service is reached by the worker roughly at the age of 30 .

the workgroup the individual belonged to and on his personal wage rate. As wages per capita were pegged by the enterprise on roughly the same level in all the groups, differences in the actual and expected economic positions could be caused only by personal wage rates. These rates, set primarily on the basis of enterprise or professional service, moved rapidly upward until the individual reached the age of 30 and then definitively stopped. As a result, workers over 30 earned a relatively good living, while their fellowworkers under 30 were making a rather bad one. The other side of the coin: workers over 30 had no prospects of wage increase, and management policies put them in a hopelessly deteriorating position, while younger workers enjoyed rapidly growing wages and in this way were partly compensated for losses caused by piece-rate cuts.

(2) The second factor is the individual's actual and expected economic position out of the organization (this factor is closely connected with the previous one, as the main sources of the worker's income are his wages). People over 30 usually had a well-balanced household budget. They generally had their own family houses, well-furnished and mechanized. They had paid debts connected with the building or purchasing of their homes. They were oriented toward obtaining the available durable goods, such as television sets, refrigerators, washing machines, motorcycles, etc. To the wages of the head of the family the 
earnings of the wife were also added - she could also have a job when their children reached school age. Workers under 30 , on the other hand, carried vast burdens of fundamental investments connected with the establishment of family life. They were indebted to the savings bank, as they turned vast sums of money to building or getting a house, to furnish it etc. Moreover, since their children were small, their wives usually could not take a job (in the differences of the economic positions of families, as we have seen, a dominant role was played by the country's housing shortage, which exerted very strong pressure on household budgets for several years in the worker's life).

On the basis of these two economic factors and some others connected with them, workers were divided into two major strata with divergent interests and various powers. The age of 30 seemed to be the economic (and not demographic) dividing line.

Workers over 30 vigorously resisted management's efforts aimed at the unconditional maximization of workgroup production. Instead, they were in favor of the optimization of group output. Optimization meant a temparary maximization (to exploit the upward trend of production and wages stimulated by management), followed by a temporary slowdown (to avoid the scope of piecerate cuts, jeopardizing their actual positions). Their objective represented a form of rational acccommodation to the contradictory features of the management's incentive policy and was based on the consideration of the state of their household budget as well. Slowdowns and drops in wages (connected with optimization) were made possible by their flexible needs for money, by their relatively high earnings within the organization, and by the sound economic position of their families.

Workers under 30 , on the other hand, had no alternatives to choose between and acted almost entirely under the economic pressure of their positions. Their needs for money were inflexible as a result of their relatively low individual earnings and the vast expenses of their household budgets. They met the management's claims to maximize workgroup performance, though reluctantly. They aimed their activities at extracting the most possible money from the company regardless of the consequences.

The powers of the two strata of labor, clashing within the framework of the group, were not equal. The older workers (over 30) built up an extended informal organization and occupied nearly all formal positions of power in many workgroups. The existence of their informal 
organization, based on the compromise of fairly flexible individual interests, originated from the members' being cornered by management and, in a sense, by younger workers as well. People under 30 usually had fewer powers and were also at the mercy of their environment within the factory. The pattern of conflicting interests and powers within labor, which the managers tried successfully to exploit on the principle of divide et impera, had an effect also on the sharpness of the overall confrontation between employers and employees. Labor, torn by internal clashes, was unable in most cases to build up an efficient resistance against management, and that made a considerable contribution to the permanence of chronic disagreement.

\section{Various patterns in the behavior of labor}

Workgroups showed significant differences in their behavior concerning performance and personal wage differentials. In accordance with our proposition, they also showed corresponding significant differences in their patterns of interests and powers. The various characteristics of workgroup behaviour can be deduced from the conflicting and interacting interests and powers of the two major strata of workers and of labor and management, and from the socioeconomic environment in the background.

We have found three significant types of workgroup behavior in the fields discussed.

Table 4

Workgroup behavior concerning performance and personal wage differentials.

\begin{tabular}{|c|c|c|c|}
\hline Types & $\begin{array}{l}\text { Number } \\
\text { of } \\
\text { groups }\end{array}$ & $\begin{array}{l}\text { Workgroup behavior } \\
\text { concerning } \\
\text { performance }\end{array}$ & $\begin{array}{l}\text { Level of individual } \\
\text { differentials approved } \\
\text { by group }\end{array}$ \\
\hline Type I & 10 & Optimization & Medium (index: 0.09) \\
\hline Type II & 5 & Maximization & High (index: 0.13 ) \\
\hline Type III & 4 & Maximization & Very low (index: 0.01 ) \\
\hline
\end{tabular}

Workgroups belonging to the three separate types had different social composition: they all were recruited from the two major strata of workers, but in various ratios. 
Table 5

Socioeconomic background of workgroup membership.

\begin{tabular}{|c|c|c|c|c|c|c|}
\hline \multirow[t]{2}{*}{ Types } & $\begin{array}{l}\text { Workers } \\
\text { above the } \\
\text { age of } 30\end{array}$ & $\begin{array}{l}\text { Skilled } \\
\text { workers }\end{array}$ & $\begin{array}{l}\text { Workers } \\
\text { with enter- } \\
\text { prise service } \\
\text { above } \\
10 \text { years }\end{array}$ & $\begin{array}{l}\text { Workers } \\
\text { having a } \\
\text { family }\end{array}$ & $\begin{array}{l}\text { Workers } \\
\text { having } \\
\text { their } \\
\text { own home }\end{array}$ & \multirow[t]{2}{*}{$\begin{array}{l}\text { Average level } \\
\text { of personal } \\
\text { wage rates } \\
\text { in group } \\
\text { in forints }\end{array}$} \\
\hline & & \multicolumn{4}{|c|}{ Related to the whole of membership (\%) } & \\
\hline Type I & 65.1 & 80.3 & 53.0 & 77.7 & 60.8 & 8.35 \\
\hline Type II & 32.8 & 78.2 & 25.2 & 51.5 & 32.8 & 7.85 \\
\hline Type III & 84.3 & 50.5 & 41.1 & 73.7 & 78.9 & 8.23 \\
\hline
\end{tabular}

Type I. The great majority of group members were older workers (over 30), while younger people (under 30 ) were in the minority. The older workers were instrumental to one another in the following way: they joined together, built up a powerful informal organization covering an average 70 percent of group membership, and seized all possible means of formal power - occupying the positions of group leaders and trade union functionaries, and also having several Communist Party members among them. The informal organization served as an agency through which members obtained and evaluated information about their environment. It worked out normative rules for collective activity in order to control the aspects of economic and social environment that were of consequence to individual members. It functioned as a defense, endeavoring to protect its members and to extract the most possible for them from their common "enemy". It carried out the optimization of workgroup productivity, blocking the deterioration of the economic positions of workers and keeping their wages, in comparison with their efforts, at a maximum. Younger workers (under 30) were isolated individuals out of the framework of informal organization. They were forced, by the substantial powers of the older people, to adopt optimization of output. Though it did not always suit their interests - their inflexible and pressing needs for money - they could perceive its advantages and worked in relatively peaceful coexistence with the others. The members of the informal organization, though a decrease in individual wage differences momentarily contradicted their interests, set personal wage-rate differentials on a medium (0.09) instead of a high level. In such a way they made a concession to the younger workers to 
ensure better cooperation within the workgroup against management. Groups in Type I, owing to their highly-developed and one-centered informal organization, were capable of counterbalancing, to a remarkable extent, the powers of management. Sometimes they succesfully undermined management attempts directed against them; at other times they suffered defeat, but they never capitulated, and that is why they usually lived in a peaceful atmosphere in the organization. Some groups, owing to their extraordinary cohesiveness and to their monopolistic position in the process of production, even managed to reach very high average wages far beyond the level pegged by the enterprise.

Type II. The membership of workgroups was formed by a great majority of younger workers (under 30 ) and a small minority of older people (over 30); in fact, the composition was opposite to groups of type I. The informal organization was weak and divided into opposing units, as both the older and younger workers created their own informal bonds of solidarity to protect their interests. At the same time, the means of formal power were also divided between the two strata: both occupied group-leader, trade-union functionary, and Communist Party positions. Older workers, however, since they were a small minority and since their powers proved to be weak, were forced to give up their original objectives and surrender to the maximization of output urged by their younger fellow-workers and by the management as well. This capitulation resulted in a permanent deterioration of their positions, caused by continual "bloody" piece-rate cuts. Thus confrontation, in a rather sharp form, became lasting within the groups. The high-level individual wage differentials $(0.13)$ can be explained on the basis of these intralabor clashes. Workers over 30 were unwilling to make a concession to younger people, as cooperation against the management was by no means possible. They were fighting, in this case with considerable success, to preserve a high level of personal wage-rate differentials, favorable to them.

The workgroups, torn by internal struggles, could not counterbalance the powers of the management. The older workers, brought to bay by their mates, suffered deeply hurting defeats by continual piece-rate cuts, while younger people - though somewhat compensated by the growth of their personal wage rates - were also hurt.

Type III. The members of these workgroups belonged to the strata of older workers, whose best interests, under the circumstances of the company, required the optimization of output. This form of self- 
defense and deliberate exploitation of the enterprise was, however, made impossible here by certain factors of physical and economic environment not mentioned before. The primitive preparatory operations in the unit were done by these groups, while the others were engaged in the more complicated building of the railroad car body. The existence of a group incentive in types I and II was justified by the collective nature of work, while in these groups it was introduced to simplify administration. The workers, only a few in number, performed their tasks separately from each other in the different corners of the shop, and in more shifts. The nature of the work, the lack of permanent collective activities, kept people back from forming strong informal bonds among themselves that were essential for the optimization of output. Furthermore, per capita wages, being on a roughly equal level in all the other groups, were here kept very low by the management, also as a result of the primitive individual tasks. Under the pressure of these circumstances, the only choice for groups was the maximization of productivity: people were forced to make increasing contribution to enterprise objectives for nearly the same amount of money. As a primitive form of defense they decreased differences in personal wage rates to a minimum (0.01). However, their defenselessness reached a high level and their opposition to management was intensive.

The various types of workgroup behavior in the field of performance and setting wage differentials have been thus deduced from the structure of interests and powers within the workgroup (intralabor relations) and within the company (labor-management relations), based on the whole of the socioeconomic environment. The various types of workgroup behavior gave different results: some workgroups managed to reach exceptionally high wages beyond any limits set by the enterprise or by the central agencies, while the wages of others were very low. Some workgroups carried out their activities at a comfortable pace, while others came under the pressure of tight piece rates.

To put together the results of workgroup behavior and the facts about intralabor and labor-management relations, let us look at table 6 .

\section{Conclusions}

The experiences of the sociological survey seem to support the proposition put forward convincingly: difficulties on the shop floor, 
Table 6

Level of wages and piece rates in workgroups; intralabor and labor-management relations in groups.

\begin{tabular}{|c|c|c|c|}
\hline \multirow{2}{*}{ 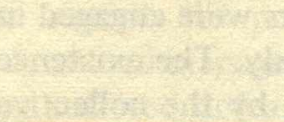 } & \multicolumn{3}{|l|}{ Types of groups } \\
\hline & Type I & Type II & Type III \\
\hline $\begin{array}{l}\text { Monthly wages } \\
\text { per capita }\end{array}$ & high & medium & low \\
\hline Level of piece rates & loose or normal & normal or tight & very tight \\
\hline \multicolumn{4}{|l|}{ Intralabor relations: } \\
\hline Structure of interests & $\begin{array}{l}\text { workable compro- } \\
\text { mise between two } \\
\text { strata }\end{array}$ & $\begin{array}{l}\text { chronic conflicts } \\
\text { between two strata }\end{array}$ & no definite structure \\
\hline Structure of powers & $\begin{array}{l}\text { one-centered power- } \\
\text { ful informal organi- } \\
\text { zation }\end{array}$ & $\begin{array}{l}\text { divided weak in- } \\
\text { formal organization }\end{array}$ & $\begin{array}{l}\text { only casual informal } \\
\text { bonds among mem- } \\
\text { bers }\end{array}$ \\
\hline \multicolumn{4}{|l|}{$\begin{array}{l}\text { Labor-management } \\
\text { relations: }\end{array}$} \\
\hline Structure of interests & low level of conflicts & high level of conflicts & high level of conflicts \\
\hline Structure of powers & $\begin{array}{l}\text { relative equilibrium } \\
\text { of powers }\end{array}$ & $\begin{array}{l}\text { permanent disequi- } \\
\text { librium of powers }\end{array}$ & $\begin{array}{l}\text { complete defenseless- } \\
\text { ness of workers }\end{array}$ \\
\hline
\end{tabular}

including also the inadequacies of the incentive system, have their root cause in the structure of divergent interests and various powers within the enterprise. The decrease in individual wage differentials carried out by labor in opposition to management's goals, the occasional deliberate slowdown of production by a remarkable number of workgroups, and the high level of manpower mobility all are symptoms of labor-management and intralabor conflict situations, and also those of disequilibrium of powers. In this respect, the indices of mobility are also worth mentioning. In type I - where tension was relatively low owing to the considerable powers of workers - only 21 percent of members left the enterprise during one-and-a-half years. In types II and III - where confrontation was especially sharp owing to the defenseless situation of certain strata - about 60 percent of workers gave notice to the firm in the same period.

The features of the structure of powers played an especially important role. The lack of proper division of the means of power among the 
participants in production resulted in very grave consequences. We also had an impression that not only was the division of power imperfect, but the whole amount of means at the disposal of the organization was insufficient. The company seemed to be too much tied up by central regulations to be capable of finding more satisfactory solutions for its pressing problems. The participation of labor can scarcely be imagined if the management itself does not have enough freedom in vital decisions (for example, about the level of wages).

As the structure of interests and powers is basically determined by the socioeconomic environment, the difficulties in the workshops can be overcome only by fundamental coordinated modifications in the complex of micro- and macrosocioeconomic factors. The prevailing belief in Hungarian society that problems vis-a-vis labor can be solved by the revision of incentive plans, by the introduction of fair wage differentials, that is, by the change in a sole microeconomic factor, is profoundly naive, as proved also by the example of the enterprise examined. The major factors having an influence on the cource of occurrences within the factory are the following.

(1) In macro- (that is, national) measures the major factor is the regulations of the central agencies of economy, such as the profit sharing system, the control over wages per capita, the practice of setting prices at the internal market and of giving subsidies for business organizations, the system of credits for company investments - in one word, the state of the decentralized scheme of the centrally planned economy introduced in 1968 . We can enlist here also regulations directly affecting labor: the central measures directed at the welfare of the population (the social insurance system, the housing program), the policy of taxation, etc. Rules outlining the construction and functioning of social institutions, such as trade unions, should also be mentioned here. The central regulations are based on a scientific analysis of the economic and social realities that have been in existence for the past few decades, and include complicated social, humanitarian, and political preferences. That is why change, though essential, because of a number of negative side effects, cannot be a rapid process.

(2) In micro-(enterprise) measures the main factors are the incentive policies of the management (the wage plan of the workers, the system of personal wage rating, the incentives for foremen and other middle managers, the practice of piece-rate setting, etc.), the aspects of promotion, the functioning of trade-union and other social organizations, the 
state of the decentralization of internal decisions, the construction of institutions for labor's participation, the existence and stability of informal organization, the social composition and stratification of workers, the effects of their out-of-factory environments and traditions, and so on. Though all these microfactors are closely connected with the macro ones, certain improvement in the solution of conflict situations can be achieved even by their revision within the limits of the enterprise possibilities, if the modifications are based on careful consideration.

The following step forward, however, requires the contribution of the social sciences: much more emphasis should be laid on the definition of the main groups of participants and the conditions under which they are motivated to participate and to produce, on processes by which multiple centers of power and influence develop and on conflict resolution as a subject of importance not only in labor-management relations but in most other intergroup relations within the firm as well. 